Dhaka Univ. J. Biol. Sci. 24(1): 59-64, 2015 (January)

\title{
INFLUENCE OF GENDER DIFFERENCES ON PERSONALITY CHARACTERISTICS : A STUDY OF URBAN AND RURAL CHILDREN
}

\author{
Fahema Sultana ${ }^{1}$ And Mst. Maleka Pervin* \\ Department of Psychology, University of Dhaka, Dhaka-1000, Bangladesh
}

Key words: Gender differences, Personality characteristics, Urban and rural children

\begin{abstract}
Effects of gender and place of residence on personality characteristics of children were studied. A total of 400 children were the sample of this study of which 200 were from urban and 200 from rural area. Results revealed that male children were more aggressive than female. There was no difference between urban and rural children in aggressiveness vs submissive-ness. The effects of gender and residence on extroversion vs introversion were not significant. The male children were more relaxed than female children. The effect of residential status on relaxed vs tense was not significant.
\end{abstract}

\section{Introduction}

Personality can be defined as the unique patterning of behavioral and mental processes that characterizes an individual and the individual interactions with the environment. Longitudinal studies on children have revealed that many personality trait and temperamental characteristics of infants tend to continue into childhood, and even into early adulthood ${ }^{(1,2)}$. Resing et al. tested five-factor-model (Extroversion, attitude towards school work, aggressiveness, and emotional stability) which was valid for the description of individual differences in Dutch school children ${ }^{(3)}$.

Joshi found that females were higher on neuroticism and anxiety whereas males were higher on extroversion ${ }^{(4)}$. Ahmad concluded that female graduate students were comparatively more prone to higher worry than male(5). Weine et al. showed that boys scored higher on the attention problems, delinquent behavior, and aggressive behavior ${ }^{(6)}$. Some workers suggested that women are less aggressive than men ${ }^{(7,8)}$. Gender differences either do not exist or exist only at specific developmental period ${ }^{(9-11)}$. Loeber and Hay found that only pre-school period do clear gender differences emerge, with more boys than girls displaying personal aggression and physical ${ }^{(12)}$. Begum found that according to mothers $2.2 \%$ of boys and $1.5 \%$ of girls and according to teacher $2.6 \%$ of boys and $1.6 \%$ of girls have aggressive behavior in the clinical range ${ }^{(13)}$. She also noted that, on all items

\footnotetext{
*Author for correspondence: <molifa07@gmail.com>. ${ }^{1}$ Department of Psychology, Siddheswari Girls' College, Dhaka, Bangladesh.
} 
boys were judged to have significantly higher aggressive behavior than girls. Kato et al. found that personality traits like being extroverted, enjoying laughten and staying engaged may be part of the longevity genes mix that allows some people to live very long lives ${ }^{(14)}$.

The period of childhood is significant for personality development. Heredity and environment also have a great impact on personality development. Moreover, a survey of literature on the development of a child's personality showed that the most important factors exerting major influence are gender and environment. The present study was, therefore, conducted on school children in rural and urban areas to explain personality. The findings of this study may be helpful for parents, teacher and child counselor who are concerned with children's welfare and development.

\section{Materials and Method}

Present study comprised of 400 children of whom 200 (117 boys and 83 girls) were from urban area (Dhaka city) and 200 (84 boys and 116 girls) were form rural areas (Kapasia Thana, Gazipur). The age of the respondents ranged from $10-12$ years and their educational level ranged from class V to VII. The respondents were selected from four schools of Dhaka city and four schools of Kapasia Thana. All of the schools are of coeducation system.

A personality scale for children was applied to collect data along with a demographic and personal information form, to measure personality characteristics of children ${ }^{(15)}$. This scale was an 80-item-questionnaire on a two-point-scale ranging from 0 (no) to 1 (yes). Summation of all the items in a sub-scale will be the total score in that particular subscale. The questionnaire comprised of three dimensions sub-scales which were grouped broadly as aggressiveness vs submissiveness, extroversion vs introversion, and relaxed vs tense. Aggressiveness vs submissiveness scale consists of 24 items in which aggressive includes dominating, hostile, arrogant, vindictive, tough-mined, argumentative, and short-tempered whereas submissive includes obedient, modest, generous, adaptive, calm, loyal, sympathetic, gentle and warmhearted. In that sub-scale, high score indicated aggressive and low score indicated submissive. Fourteen items were for extroversion vs introversion scale where introvert means unfriendly, unsociable, shy, quite, reserved while extrovert means friendly, humorous, social, lively, company seeking, gregarious, adventurous, bold, straight forward and talkative. Here high score indicated extrovert and low score means introvert. Lastly 20 items were for relaxed vs tense scale where relaxed means carefree, sober and sound, easily-adjustable, easygoing, capacity to take any decision quickly and on the other hand tense means anxious, inattentive, doubting, nature, have some specific somatic disorders, feeling helpless, timid, impatient, careless, highly ambitious and unable to accept the situation. In this situation, high score indicated tense and low score indicated relaxed. 
Standard data collection procedures were followed in the study. The respondents were requested to go through each statement carefully and if it was true in their case, they were asked to put tick $(\sqrt{ })$ mark on 'Yes' but if it was not true then they were asked to put tick $(\sqrt{ })$ mark on ' $\mathrm{No}^{\prime}$. After completion of their task, the questionnaire was collected and they were given thanks for their sincere cooperation.

\section{Results and Discussion}

The data were analyzed by using ANOVA. The results are presented in tables 1 to 5 . Table 2 shows that the main effect of gender on aggressiveness vs submissiveness was found to be significant $(\mathrm{F}=16.185, \mathrm{df}=1,396, \mathrm{p}<0.01)$ and it was apparent from Table 1 that male children were more aggressive than female children. The main effect of residence and interaction effect between gender and residence regarding aggressiveness vs submissiveness were not found to be significant. This indicates that the urban and rural children do not differ in respect of aggressiveness vs submissiveness and the effects of gender and residence on aggressiveness vs submissiveness are independent.

Table 1. Mean aggressiveness vs submissiveness scores of children by gender

\begin{tabular}{cccc}
\hline Gender & $\mathrm{N}$ & Mean & Sd \\
\hline Male & 202 & 7.40 & 4.96 \\
\hline Female & 199 & 5.64 & 3.92 \\
\hline
\end{tabular}

Table 2. ANOVA of aggressiveness vs submissiveness as a function of gender and residence of the participants.

\begin{tabular}{lcccc}
\hline Source of variance & SS & df & MS & F \\
\hline Gender & 325.068 & 1 & 325.064 & $16.185^{*}$ \\
Residence & 16.770 & 1 & 16.770 & 0.835 \\
Gender x Residence & 7.820 & 1 & 7.820 & 0.388 \\
Error & 7953.333 & 396 & 20.084 & \\
\hline
\end{tabular}

${ }^{*} \mathrm{p}<0.01$.

Table 3 shows that the main effect of gender, residence and the interaction effect between gender and residence regarding extroversion vs introversion were not found to be significant. Table 5 shows that the main effect of gender on relaxed vs tensed score was found to be significant $(\mathrm{F}=11.237, \mathrm{df}=1,396, \mathrm{p}<0.01)$ and it is apparent from Table 4 that male children were more relaxed than female children. The main effect of residence on relaxed vs tense and interaction between gender and residence were not significant. This means that urban and rural children do not differ in respect of relaxed vs tense and the effect of the gender and residence are independent. 
The result showed that gender had significant effect on aggressiveness vs submissiveness of the children $(\mathrm{F}=16.185, \mathrm{df}=1,396, \mathrm{p}<0.01)$. The findings indicated that boys were more aggressive than the girls and it was consistent with the findings of previous workers $(7,8,12,13)$. Roberts and Bird found that in home, in the school and in the neighborhood boys break more rules and show more aggressive behavior than girls ${ }^{(16)}$. There are two possible reasons for this gender difference. First, boys are given more freedom than girls and are less punished for misbehavior on the grounds that "boys are to be rough", and second, boys often defy rules to show their masculinity and thus win peer approval. Begum found that Bangladeshi girls are discouraged from early childhood to express any aggressive behavior and society also shows negative attitude towards female showing such behavior. Boys on the other hand are either encouraged, or at least allowed to express aggression in many situation. For these reasons boys may show aggressive behavior than girls.

Table 3. ANOVA of extroversion vs introversion as a function of gender and residence of the participants.

\begin{tabular}{llccc}
\hline Source of variance & SS & df & MS & F \\
\hline Gender & 3.331 & 1 & 3.331 & 0.412 \\
Residence & 2.283 & 1 & 2.283 & 0.283 \\
Gender $\times$ residence & 6.096 & 1 & 6.096 & 0.755 \\
Error & 3199.103 & 396 & 8.079 & \\
\hline
\end{tabular}

Table 4. Mean relaxed vs tense scores of children by gender.

\begin{tabular}{lcccc}
\hline Gender & $\mathrm{N}$ & Mean & SD \\
\hline Male & 201 & 8.71 & 3.90 & \\
\hline Female & 199 & 9.99 & & 3.54 \\
\hline
\end{tabular}

Table 5. ANOVA of relaxed vs tense as a function of gender and residence of the participants.

\begin{tabular}{lllll}
\hline Source of variance & SS & df & MS & F \\
\hline Gender & 157.094 & 1 & 157.094 & $11.237^{*}$ \\
Residence & 1.099 & 1 & 1.099 & 0.079 \\
Gender Residence & 3.703 & 1 & 3.703 & 0.265 \\
Error & 5535.895 & 396 & 13.980 & \\
\hline
\end{tabular}

${ }^{*} \mathrm{p}<0.01$.

The effect of residence on aggressiveness vs submissiveness was not found to be significant. That is, there was no difference between rural and urban children regarding aggressiveness vs submissiveness. Research indicated that personality is a dynamic totality which is continuously changing due to interaction with the environment or 
society. Today the influence of mass media and the development of technology, the rural environment are gradually changing, and the personality of the children is not fixed or matured. Milgram and Helper found that social desirability is a powerful influence on self-report ${ }^{(17)}$. In the present study, participants were asked to write down their name, age, class and roll number in the personal information sheet. So it is quite reasonable to believe that even if they were aggressive they would not express it openly since it was socially undesirable particularly in our culture. The interaction effect between gender and residence was not found to be significant. This indicates that there were no significant effect of gender and place of residence jointly on personality characteristics of children.

The effects of gender, residence and the interaction effect between gender and residence regarding extroversion vs introversion were not significant. This findings means that most of the people of our society always encourage to express introvert characteristics of the children, and for this reason, children try to suppress their extrovert behavior in front of people.

The result showed that the effect of gender on relaxed vs tense was significant. The male children were more relaxed than female children. The finding is consistent with the findings of previous research. Dube found that significant gender differences in the perception of different life events as stressful(18). Ahmed found that female were comparatively more prone to higher worry than male(19). Boys are given greater autonomy, are encouraged by the parents to become independent than the girls. They are involved in physically active games, so they become more relaxed. But in girl parental overprotection or pressure and negligence may cause the tension of female children in Bangladesh. The effect of residence on relaxed vs tense was not found to be significant. At present, Bangladesh is going through political and social crisis which is affecting rural and urban area equally especially areas which situated near Dhaka city. This is why no significant residential differences were found in respect of relaxed vs tense.

The present research has thrown some light on the personality characteristics of both rural and urban children. Knowledge of personality characteristics of children is necessary for mothers, teachers and those who are concerned with children's welfare and development.

\section{References}

1. Carey WB and SC McDevitt 1978. Stability and change in individual temperaments: Diagnosis from infancy to early childhood. J. Amer. Acad. Child Psychol. 17: 331-337.

2. Kagan J and HA Moss 1962. Birth to maturity. John Wiley and Sons, New York.

3. Resing W CM, N Bleichrodt and PH Dekker Peter 1999. Measuring personality traits in the classroom. European J. Personality 13(6):493-509. 
4. Joshi K 1993. Study of level of anxiety and personality traits of teachers and students. Paper presented at the $30^{\text {th }}$ IAAP conference, Jodhpur.

5. Ahmed A 1996. Influence of sex differences on test anxiety a study of graduate students. Paper presented at the $1^{\text {st }}$ Asian and $2^{\text {nd }}$ IAAIP conference, Aligarh.

6. Weine AM, JS Philips and TM Achenbach 1995. Behavioral and emotional problems among Chinese and American children: Parent and teacher report for ages 6 to 13. J. Abnormal Child Psychol. 23(5): 619-639.

7. Elliot DS 1994b. Serious, violent offenders: onset, developmental course, and termination. The American Society of Criminology Presidential Address. Criminol. 32: 1-21.

8. Maccoby EE and CM Jacklin 1974. The Psychology of Sex Differences. C.A. Stanford University Press.

9. Cotton NU, J Resnick, DC Browne, SL Martin, DR McCarraher, and J Woods 1994. Agression and fighting behavior among African-American adolescents: Individual and family factors. Amer. J. Public Health 84: 618-622.

10. RG Sheldon, and M Chesney-Lind 1993. Gender and race differences in delinquent careers. Juvenile and Family Court Journal 44:73-90.

11. Tieger T 1980. On the biological basis of sex differences. Child Development 51: 943-963.

12. Loeber R and DF Hay 1997. Key issues in the development of aggression and violence from childhood to early adulthood. Annual Review of Psychology 48: 371-410.

13. Begum R 1996. Sex differences in aggressive behavior in children: Parents and teacher's reports. Bangladesh J. Psychol. 16: 81-90.

14. Kato K, R Richard Zweig, N Brazilia and G Atzmon 2012. Positive attitude towards life and emotional expression as personality phenotypes centenarians. Impact J. Aging. 4(5): 359367

15. Mahtab JS 1994. Development of a Personality Scale for Children. Master's Thesis, University of Dhaka.

16. Roberts J and JT Bird 1972. Behavioral patterns of children in school: United States, Rockville, Md: U.S. Department of Health, Education and Welfare.

17. Milgram NA and MM Helper 1961. The social desirability set in individual and grouped selfratings. J. Consulting Psychol. 25: 91.

18. Dube S 1980. Scaling of life events: A cross cultural study in the community setting of Delhi. Paper Presented at the 5th International Conference of Cross-cultural Psychology, Bhubaneswar.

(Manuscript received on 23 March, 2014; revised on 31 December, 2014) 